\title{
ОФТАЛЬМОХІРУРГІЯ
}

\author{
Н. В. Новак \\ Київська міська клінічна офтальмологічна лікарня “Центр мікрохірургії ока” МОЗ України
} - м. Київ, Україна

\section{ПОРІВНЯЛЬНА ЕФЕКТИВНІСТЬ КОМБІНОВАНОГО МЕТОДУ ХІРУРГІЧНОГО ЛІКУВАННЯ ВТОРИННОЇ НЕОВАСКУЛЯРНОЇ ГЛАУКОМИ}

\begin{abstract}
Одним із найтяжчих ускладнень судинних захворювань сітківки є вторинна неоваскулярна глаукома (ВНГ).

Мета роботи - вивчення ефективності та безпеки методу хірургічного лікування ВНГ, який включає поетапне зниження внутрішньоочного тиску.

Матеріали і методи. Проведено аналіз перебігу захворювання у 118 хворих на ВНГ.

Результати та їх обговорення. Запропонований метод забезпечує гіпотензивний ефект у 86,0 \% хворих та зменшення геморагічних ускладнень до 16 \%.

Висновки. Запропонована комбінована операція має меншу кількість як інтра-, так і післяопераційних ускладнень, забезпечує стійкий гіпотензивний ефект та збереження зорових функцій у віддаленому періоді.

Ключові слова: вторинна неоваскулярна глаукома, комбіноване лікування, поетапне зниження внутрішньоочного тиску, неоваскуляризація.
\end{abstract}

Протягом останнього десятиліття помічається зріст судинних захворювань серед населення земної кулі. У зв’язку з цим лікування судинної патології органа зору та іiі ускладнень залишається актуальною проблемою сучасної офтальмології $[1,5]$.

Одним із найтяжчих ускладнень судинних захворювань сітківки - таких, як проліферативна ретинопатія, тромбоз центральної вени сітківки, очний ішемічний синдром - є вторинна неоваскулярна глаукома $[5,8]$.

Відомо, що в основі неоваскулярної глаукоми лежить патологічне новоутворення судин у райдужці на куті передньої камери ока. Пусковим моментом прогресуючої неоваскуляризації переднього відділу судинного тракту є ішемія сітківки, що виникає на фоні порушення іiі кровообігу.

Неоваскулярну проліферацію індукують ангіогенні фактори (ендотеліальний судинний фактор росту VEGF та інші), які виробляються внутрішніми шарами сітківки в стані іiі гіпоксії. Новоутворені судини мають тонку порозну стінку як наслідок неповноцінного ендотеліального покриття і характеризуються здатністю до геморагій $[4,5,6]$. Новоутворена фіброваскулярна тканина в подальшому своєму розвитку має тенденцію до ретракції, в результаті якої утворюються гоніосинеxiї. Поширення процесу по периметру кута передньої камери призводить до його блокади. Перенасичення внутрішньоочних тканин новоутвореними судинами, їхнє близьке розташування до зони фільтрації створює блок відтоку внутрішньоочної рідини, результатом чого виникає декомпенсація внутрішньоочного тиску, підвищення ризику внутрішньоочних крововиливів $[1,3,8]$.

У зв'язку 3 недостатньою ефективністю медикаментозної терапії пріоритетним напрямком у нормалізації внутрішньоочного тиску (ВОТ) та стабілізації зорових функцій $є$ хірургічне лікування $[5,6,15]$.

Хірургічні методи лікування НВГ направлені на формування штучних шляхів відтоку внутрішньоочної рідини - фістулізуючі операції, операції з використанням різноманітних імплантів та дренажних систем. Але більшість існуючих хірургічних втручань пов'язані з високим ризиком інтра- та післяопераційних ускладнень геморагічного характеру внаслідок як високого ВОТ, так і наявності новоутворених судин райдужки та кута передньої камери ока. 
Геморагічні ускладнення та підвищена проліферація сполучної тканини в зоні операції зменшують гіпотензивний ефект хірургічного втручання та обмежують можливість застосування операцій при вторинній неоваскулярній глаукомі. Згідно даних літератури, число інтра- та післяопераційних ускладнень при виконанні фільтруючих операцій наближається до $75 \%[3,7]$. Операції непроникаючого типу, що так широко використовуються в лікуванні первинної глаукоми, характеризуються найменшим числом ускладнень, але при вторинній неоваскулярній глаукомі виявляються малоефективними через швидке рубцювання фільтраційної подушки.

Фактор неоваскуляризації визначається як субстанція, котра провокує нестримне розростання новоутворених патологічних судин, конгломерати яких призводять до виникнення різноманітних крововиливів із подальшою деструкцією тканин. На швидкість та поширення неоваскуляризації впливає концентрація ангіогенних факторів у скловидному тілі та волозі передньої камери.

3 метою зупинки прогресування вторинної неоваскулярної глаукоми та стабілізації зорових функцій $е$ важливою компенсація ВОТ, а також вплив на судинний ендотеліальний фактор росту (VEGF), що є основною причиною процесу неоваскуляризації $[11,14]$.

Ефективних методів лікування прогресуючого рубеозу райдужки практично не існує. Найбільш широко застосовується аргон-лазерна коагуляція ішемічних зон сітківки та новоутворених судин райдужки і кута передньої камери. Недоліками цього методу $\epsilon$ нетривалий характер оклюзії новоутворених судин, реактивна гіпертензія та високий ризик ускладнень запального характеру $[9,15]$. Існуючі хірургічні методи лікування такої глаукоми - як з використанням антиметаболітів, так і без них - не дають очікуваного гіпотензивного ефекту. Використання різноманітних дренажних та клапанних систем забезпечують дещо більшу ефективність, але також мають велику частку операційних ускладнень $[2,12,13]$.

Останнім часом з метою досягнення регресу новоутворених судин райдужки і кута передньої камери та зменшення частоти операційних і післяопераційних геморагічних ускладнень використовуються інтравітреальні та внутрішньокамерні ін'єкції інгібіторів VEGF як етап у лікуванні НBГ $[11,12,14]$. Як самостійне лікування анти-VEGF терапія призводить до регресу новоутворених судин райдужки та кута передньої камери, зменшує проникність судин, призводить до часткового зниження ВОТ. Але досягнутий гіпотензивний результат не довготривалий (4-6 тижнів) $[7,15]$, тому стає необхідною хірургія глаукоми 3 метою створення фільтраційної фістули $[2,11,12,14]$.

Однак, ні ізольоване використання анти-VEGF препаратів, ні їх комбінація з традиційними хірургічними втручаннями не дають очікуваного результату.
Пошук нових, патогенетично орієнтованих методів хірургічного лікування ВНГ, профілактика інтра- та післяопераційних ускладнень залишаються актуальним завданням сучасної офтальмології, обумовлюють пошук та створення нових технологій для хірургічного лікування ВНГ.

Мета роботи - вивчення ефективності та безпеки методу хірургічного лікування ВНГ, який включає поетапне зниження ВОТ на фоні використання анти-VEGF терапії.

Матеріали і методи. Під нашим спостереженням знаходилось 118 хворих (118 очей) віком від 48 до 72 років, з них 66 жінок та 52 чоловіки. У 44 хворих неоваскулярна глаукома виникла внаслідок тромбозу ЦВС, у 74 хворих - ії гілок. Тривалість захворювання склала від 6 до 12 місяців.

Усі 118 хворих (118 очей) були нами прооперовані. Із них 44 хворим (44 ока), що склали 1-у групу спостереження, була виконана запропонована нами з метою поетапного зниження внутрішньоочного тиску комбінована антиглаукомна операція: поєднання глибокої непроникаючої склеректомії по Федорову-Козлову із субсклеральною циклвітректомією по Сергієнку 3 одного хірургічного доступу на першому етапі та лазерна трабекулотомія (ЛТТ) в модифікації СергієнкаКондратенка на другому етапі.

2-y групу спостережень склали 36 пацієнтів (36 очей), яким було проведено запропоноване нами хірургічне лікування, яке включало поєднання глибокої непроникаючої склеректомії по Федорову-Козлову 3 одномоментним інтравітреальним введенням препарату антипроліферативної дії. Другим етапом виконувалась ЛТТ у модифікації Сергієнка-Кондратенка.

3-ю, контрольну групу спостережень склали 38 хворих (38 очей), яким було виконано комбіновану операцію синустрабекулоектомія по Нестерову в поєднанні з субсклеральною циклвітректомією по Сергієнку з одного хірургічного доступу.

У пацієнтів трьох груп був вивчений гіпотензивний ефект операції, простежені віддалені результати запропонованого хірургічного методу лікування, характер операційних і післяопераційних ускладнень та проведене їх порівняння.

Групи спостереження були статистично порівнювані за статтю, віком, стадією глаукоми, стадіями неоваскуляризації та станом кута передньої камери ока.

Усі пацієнти отримували місцеву гіпотензивну терапію (2-3 препарата). 82 хворим попередньо було проведено лазерне лікування - панретинальна або фокальна лазеркоагуляція сітківки.

Компенсації внутрішньоочного тиску від медикаментозної терапії не було отримано. Величина офтальмотонуса коливалась у межах $\mathrm{P}_{\mathrm{o}}=34,2 \pm 1.2$ мм рт.ст.

За стадіями глаукоматозного процесу хворі розподілялись таким чином: 
II-a (розвинута) стадія - 50 хворих (50 очей) $42,4 \pm 8,2 \%$;

III-я (далекозайдена) стадія - 68 хворих (68 очей) $-57,6 \pm 8,6 \%$.

Максимально корегована гострота зору від 0,01 до 0,2 дптр помічена у 92 хворих (92 очей), світлосприйняття 3 неправильною проекцією світла - у 26 хворих (26 очей). Незріла катаракта - у $79 \%$, артифакія - у $21 \%$ хворих.

Неоваскуляризація райдужки та кута передньої камери ока за класифікацією Weiss:

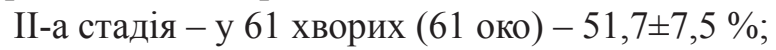

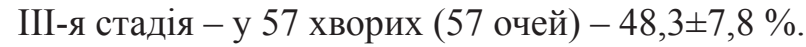

Розподіл хворих на вторинну неоваскулярну глаукому в 1, 2, 3 групах спостереження по стадіях глаукоми, стадіях неоваскуляризації та стану кута передньої камери наведений у табл. 1.

Для порівняння структури груп у відсотках $(\mathrm{p} \pm \mathrm{m})$ ми використовували метод кутового перетворення Фішера $\left(\varphi^{*}\right)$, призначений для порівняння двох вибірок по частоті ознаки, що зустрічається. Кутове перетворення Фішера дозволило оцінити достовірність відмінностей між долями двох вибірок у відсотках, в яких зареєстрована ознака, що вивчається. Нульову гіпотезу про рівність значень ознак не враховували, а відмінності між порівнюваними показниками вважали достовірними при рівні значимості $\mathrm{p}<0,05$.

Хворим у динаміці проводились: тонометрія, візометрія, динамічна периметрія, біомікроскопія, офтальмоскопія, гоніоскопія, ультразвукова біомікроскопія, оптична когерентна томографія.

Перед оперативним лікуванням усі хворі проходили загальноклінічні обстеження. Із супутніх захворювань відзначено у 94 хворих $(79,7 \pm 3,7 \%)$ гіпертонічну хворобу (ГХ) різного ступеня та ішемічну хворобу серця (IXC) у 88 хворих $(74,6 \pm 4,0 \%$ ). $\mathrm{У}$ дослідження не включали пацієнтів із системними захворюваннями, цукровим діабетом, хронічними інфекційними захворюваннями. Перед оперативним втручанням проводилась загальна гіпотензивна терапія протягом 3-5 днів.

У післяопераційному періоді всі пацієнти отримували в інстиляціях антибактеріальні, стероїдні та нестероїдні протизапальні препарати. Термін спостереження - 12 міс.

Результати та їх обговорення. Запропоноване нами патогенетично орієнтоване лікування, що включає поєднання синусотрабекулотомії в два етапи із субсклеральною цикловітректомією з одного хірургічного доступу призводить до поетапного зниження ВОТ та регресу або зменшення неоваскуляризації райдужки та кута передньої камери ока за рахунок ймовірного зменшення концентрації вазопроліферативних факторів у скловидному тілі.

Аналіз техніки запропонованої комбінованої операції та післяопераційних результатів показав, що таке поєднання хірургічних доступів забезпечує дозовану фільтрацію внутрішньоочної рідини за рахунок створення умов для відтоку як з передньої камери, так і з порожнини скловидного тіла.

Протягом 3-5 днів після хірургічного втручання неоваскулярні судини зазнавали регресу. Так, у хворих 1-ї групи спостереження новоутворені судини зникли у 33 хворих (75\%) та зменшились у 11 хворих (25\%) протягом 3-5 днів. Через тиждень неоваскулярні судини зазнали регресу у всіх хворих. У пацієнтів 2-ї групи спостереження через 3-5 днів регрес судин помічений на 30 очах $(83,4 \%)$ та зменшення неоваскуляризації - у 6 хворих (16,6 \%).

Протягом першого тижня після операції новоутворені судини у всіх пацієнтів 1-ї та 2-ї груп зазнали повного регресу.

У групі контролю неоваскуляризація зменшилась протягом 3-5 днів після операції у 19 хворих (50 \%), а протягом 7 днів після операції відбувся частковий регрес судин ще у 7 хворих $(18,4 \%)$.

При виконанні оперативних втручань та в ранньому післяопераційному періоді (протягом 1 місяця після операції) був помічений ряд ускладнень.

Так, у пацієнтів 1-ї групи спостереження гіфема інтраопераційна помічена у 7 хворих (15,9 \%), післяопераційні ускладнення: гіфема - у 4 хворих $(9,1 \%)$ та ЦХО - у 4 хворих $(9,1 \%)$. У пацієнтів 2-ї групи спостереження інтраопераційна гіфема спостерігалась лише у 2 хворих (5,6 \%). Найбільша кількість інтра- та післяопераційних ускладнень помічена у хво-

Таблиия 1

Розподіл хворих на вторинну неоваскулярну глаукому за стадіями неоваскуляризації та станом кута передньої камери ока

\begin{tabular}{|c|c|c|c|c|c|}
\hline \multirow{2}{*}{\multicolumn{2}{|c|}{ Показник }} & \multicolumn{3}{|c|}{ Aбс. $(\% \pm m \%)$} & \multirow{2}{*}{$\begin{array}{c}\text { Рівень значимост } \\
\text { відмінностей, } p\end{array}$} \\
\hline & & $\begin{array}{c}\text { Група } C \\
(n=38)\end{array}$ & $\begin{array}{c}\text { Гpyna 1-a } \\
(n=44)\end{array}$ & $\begin{array}{c}\text { Гpyna 2-a } \\
(n=36)\end{array}$ & \\
\hline \multirow{2}{*}{ Стадія глаукоми } & II & $18(47,4 \pm 8,1)$ & $14(31,8 \pm 7)$ & $18(50 \pm 8,3)$ & \multirow{2}{*}{0,20} \\
\hline & III & $20(52,6 \pm 8,1)$ & $30(68,2 \pm 7)$ & $18(50 \pm 8,3)$ & \\
\hline \multirow{2}{*}{ Неоваскуляризація (стадія) } & II & $20(52,6 \pm 8,1)$ & $22(50 \pm 7,5)$ & $19(52,8 \pm 8,3)$ & \multirow{2}{*}{0,96} \\
\hline & III & $18(47,4 \pm 8,1)$ & $22(50 \pm 7,5)$ & $17(47,2 \pm 8,3)$ & \\
\hline \multirow{2}{*}{$\begin{array}{c}\text { Гоніоскопія: кут відкритий / } \\
\text { частково відкритий }\end{array}$} & $\mathrm{B}$ & $17(44,7 \pm 8,1)$ & $22(50 \pm 7,5)$ & $24(66,7 \pm 7,9)$ & \multirow{2}{*}{0,14} \\
\hline & $\mathrm{4} / \mathrm{B}$ & $21(55,3 \pm 8,1)$ & $22(50 \pm 7,5)$ & $12(33,3 \pm 7,9)$ & \\
\hline
\end{tabular}


рих контрольної групи: інтраопераційна гіфема - на 16 очах (42,1\%), післяопераційна гіфема - у 8 хворих $(21,1 \%)$ та ЦХО у 9 хворих $(23,6 \%)$.

Поетапне зниження ВОТ дає можливість зменшити кількість геморагічних ускладнень у 2,5 разу (3 $42,1 \%$ до $15,9 \%)(\mathrm{p}<0,05)$.

Ефективність запропонованого методу хірургічного лікування оцінювалась протягом першого місяця та через 3, 6, 12 місяців; досліджувався гіпотензивний ефект операції та динаміка зорових функцій у прооперованих хворих.

1-а група спостереження. При огляді на першу добу після операції ВОТ у пацієнтів нормалізувався в межах $\mathrm{P}_{\mathrm{o}}=16,0 \pm 1,5$ мм рт.ст. у $100 \%$ очей.

Протягом першого місяця всім хворим був виконаний II-й етап операції ЛТТ.

Через 3 місяці після операції ВОТ був нормалізований ( $\mathrm{P}_{\mathrm{o}}=18,8 \pm 0,4$ мм рт.ст.) у 42 хворих (95\%), 2-м хворим призначені гіпотензивні препарати.

Через 12 місяців після операції ВОТ нормалізувався у 32 хворих (73\%) та у 12 хворих (27\%) із застосуванням гіпотензивних крапель. Межі поля зору збереглись на доопераційному рівні або розширились у 35 хворих (80\%).

2- а група спостереження. При огляді на першу добу після операції ВОТ був нормалізований у 37 хворих $(84 \%)-\mathrm{P}_{\mathrm{o}}=16,0 \pm 1,5$ мм рт.ст. та був незначно підвищений у 7 хворих $(16 \%)-\mathrm{P}_{\mathrm{o}}=22,0 \pm 1,2$ мм рт.ст. Цим пацієнтам другим етапом була виконана ЛТТ протягом 1 тижня після операції, решті хворих ЛТТ виконувалась протягом першого місяця.

Через 3 місяці після операції ВОТ був нормалізований у межах $\mathrm{P}_{\mathrm{o}}=17,17 \pm 0,18$ мм рт.ст. на 28 очах $(78 \%)$ та на 8 очах (22\%) із застосуванням гіпотензивних крапель.

Через 12 місяців після операції ВОТ нормалізувався у 31 хворого (86 \%) та у 5 хворих з додатковим застосуванням гіпотензивних крапель. Межі поля зору збереглись на доопераційному рівні або розширились у 33 хворих (92\%).

Контрольна група. При огляді на першу добу після операції гіпотонія ( $\mathrm{P}_{\mathrm{o}}=9,5 \pm 1,4$ мм рт.ст.) помічена на 8 очах (18\%). ВОТ незначно підвищився $(\mathrm{P}=24,2 \pm 1,6$ мм рт.ст.) у 10 хворих $(22,7 \%)$ та нормалізувався у 20 пацієнтів (45,5\%).

Через 3 місяці після операції ВОТ у межах $\mathrm{P}_{\mathrm{o}}=19,2 \pm 0,2$ мм рт.ст. відзначено на 22 очах (57\%) та в межах $\mathrm{P}_{\mathrm{o}}=20,0 \pm 0,2$ мм рт.ст. із застосуванням гіпотензивної терапії у 12 хворих (32\%) та гіпотонія ( $\mathrm{P}_{\mathrm{o}}=8,4 \pm 2,2$ мм рт.ст.) у 4 хворих (10\%).

Через 12 місяців після операції ВОТ нормалізувався у 23 хворих (60 \%), у 11 хворих (29\%) - із застосуванням гіпотензивних крапель та у 4 хворих (11\%) відзначена гіпотонія. Межі поля зору збереглись на доопераційному рівні або розширились у 29 хворих (76 \%).
Подальший математичний аналіз результатів i факторний аналіз дозволили виявити показники, які $\epsilon$ критичними для прогнозування ризику виникнення ускладнень як під час хірургічного втручання, так і в післяопераційному періоді.

Для аналізу ризику виникнення ускладнень було використано метод побудови логістичних моделей регресії. Було вивчено 7 факторних ознак: метод лікування, стать, вік, стадія глаукоми, стадія неоваскуляризації, стадія IXC, стадія ГХ.

Прогнозування ризику розвитку ускладнення під час операціï. Аналіз проводився відносно 118 хворих, при цьому у 25 з них під час операції розвинулося ускладнення (гіфема).

Для відбору факторних ознак (із 7 аналізованих), пов'язаних 3 ризиком розвитку ускладнення під час операції, було використано метод покрокового включення/виключення (Stepwise при порозі включення $\mathrm{p}<0,1$ та виключення $\mathrm{p}>0,3)$ ознак у багатофакторній логістичній моделі регресії. Було виділено дві факторні ознаки, пов'язані з ризиком розвитку ускладнення під час операції: метод лікування та стадія глаукоми. Модель, побудована 3 врахування виділених ознак, адекватна ( $c^{2}=25,2$ при 3 -х ступенях свободи, $\mathrm{p}<0,001)$ (рис. 1).

Площа під ROC кривою, $\mathrm{AUC}=0,80 \pm 0,04$, статистично значущо $(\mathrm{p}<0,001)$ перевищує 0,5 , що свідчить про середній ступінь вираженості ризику розвитку ускладнення під час операції за методом лікування та стадією глаукоми. При виборі оптимального порогу (за методом максимізаиії Youden index) значення чутливості моделі склало 92,0 \% (95 \% ВI 74,0 \% 99,0 \%), специфічності - 51,6 \% (95 \% BI 41,0 \% -

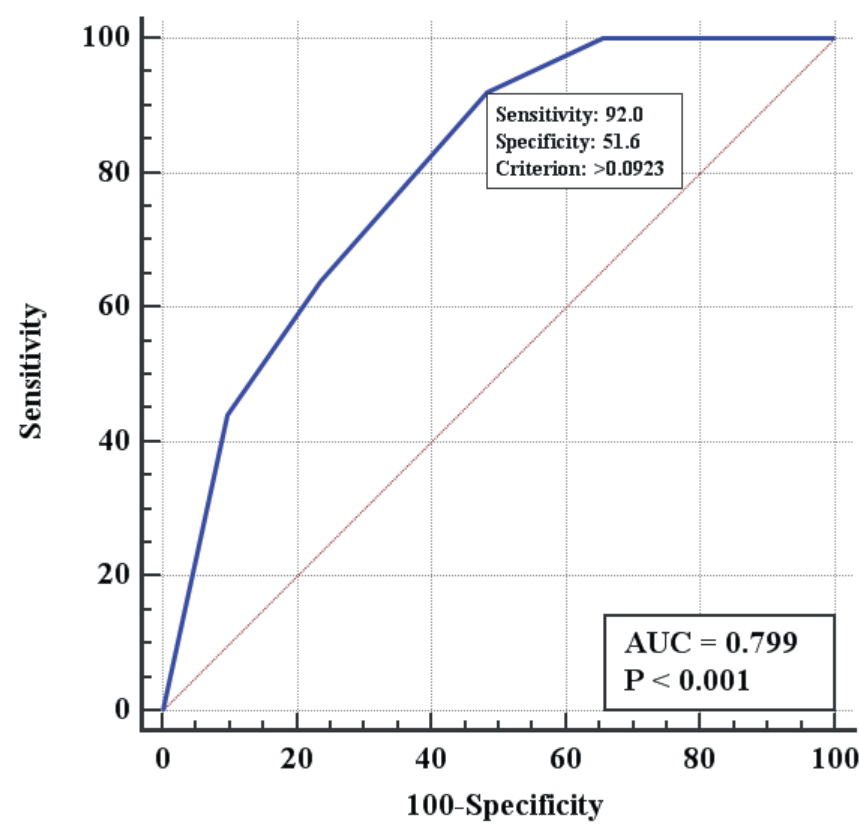

Puc. 1. ROC-крива 2-хфакторної моделі прогнозування ризику розвитку ускладнення під час операції (позначено показники чутливості та специфічності для оптимального порогу прийняття рішення) 
Коефіціснти 2-хфакторної логістичної моделі регресії прогнозування ризику

розвитку ускладнення під час операції

\begin{tabular}{|c|c|c|c|}
\hline Факторна ознака & $\begin{array}{c}\text { Значення коефіиієнта } \\
\text { моделі } \mathrm{b} \pm m\end{array}$ & $\begin{array}{c}\text { Рівень значущзості відмінності } \\
\text { коефіцієнта від 0, } p\end{array}$ & $\begin{array}{c}\text { Показник ВШ } \\
\text { (95\% ВІ ВШ) }\end{array}$ \\
\hline $\mathrm{Gr}=" \mathrm{I}$ " vs Control & $-1,73 \pm 0,58$ & 0,003 & $0,18(0,05-0,55)$ \\
\hline $\mathrm{Gr}=" \mathrm{II}$ vs Control & $-2,69 \pm 0,83$ & 0,001 & $0,07(0,01-0,34)$ \\
\hline Стадія глаукоми & $1,67 \pm 0,61$ & 0,006 & $5,3(1,6-17,3)$ \\
\hline
\end{tabular}

Коефіціснти 3-хфакторної логістичної моделі регресії прогнозування ризику

Табличя 3 розвитку ускладнення після операції

\begin{tabular}{|c|c|c|c|}
\hline Факторна ознака & $\begin{array}{c}\text { Значення коефіцієнта } \\
\text { моделі } b \pm m\end{array}$ & $\begin{array}{c}\text { Рівень значущзості відмінності } \\
\text { коефіцієнта від } 0, p\end{array}$ & $\begin{array}{l}\text { Показник ВШ } \\
(95 \% \text { ВI ВШ) }\end{array}$ \\
\hline Gr="I" vs Control & $-0,90 \pm 0,69$ & 0,19 & - \\
\hline Gr="II" vs Control & $-21,5$ & $<0,001$ & $<0,01$ \\
\hline Стать “Ч” vs “Ж” & $-1,39 \pm 0,83$ & 0,10 & - \\
\hline Стадія неоваскуляризації & $1,32 \pm 0,73$ & 0,07 & $3,7(0,9-15,7)$ \\
\hline
\end{tabular}

62,1%). Отже, із ризиком розвитку ускладнення під час операції виявлено зв'язок $(\mathrm{p}<0,001)$ для наступних факторів (табл. 2).

Таким чином виявлено зниження $(p=0,003)$ ризику розвитку ускладнення під час операції при використанні методу Gr=“II”, ВШ=0,18 (95 \% BI 0,05 - 0,55) у порівнянні з методом Control. Використання методу Gr=“II" також знижує (p=0,001), ВШ=0,07 (95 \% BI $0,01-0,34)$ у порівнянні з методом Control. Виявлено зростання $(\mathrm{p}=0,006)$ ризику розвитку ускладнення під час операції для стадії глаукоми=3, ВШ=5,3 (95 \% ВI $1,6-17,3)$ у порівнянні зі стадією глаукоми $=2$.

Згідно проведеного математичного аналізу та створення 2-хфакторної моделі прогнозування ризику виникнення ускладнень під час операції першочерговими факторами їхнього розвитку є ступінь вираженості та характер неоваскуляризації райдужки і кута передньої камери, а також стадія глаукоми. В той самий час поетапне зниження ВОТ призводить до зменшення кількості геморагічних ускладнень при хірургії ВНГ.

Прогнозування ризику розвитку ускладнення після операціï. Аналіз перебігу хвороби проводився відносно 118 хворих з ВНГ, при цьому у 12-ти 3 них після операції розвинулося ускладнення (гіфема).

Для відбору факторних ознак (із 7 аналізованих), пов'язаних з ризиком розвитку ускладнення, після операції було використано метод покрокового включення/виключення (Stepwise при порозі включення $\mathrm{p}<0,1$ та виключення $\mathrm{p}>0,3$ ) ознак у багатофакторній логістичній моделі регресії. Було виділено три факторні ознаки, пов'язані з ризиком розвитку ускладнення під час операції: метод лікування, стать та стадія неоваскуляризації. Модель, побудована на визначених ознаках, адекватна ( $c^{2}=19,3$ при 4-х ступенях свободи, $\mathrm{p}<0,001)$ (рис. 2).

Площа під ROC кривою, $\mathrm{AUC}=0,85 \pm 0,05$, статистично значущо $(\mathrm{p}<0,001)$ перевищує 0,5 , це свідчить про середній ступінь вираженості ризику розвитку ускладнення після операції за методом лікування, статтю та стадією неоваскуляризації. При вибоpi оптимального порогу (за методом максимізації Youden index) значення чутливості моделі склало 83,3\% (95 \% BI 51,6 \% - 97,9 \%), специфічності $71,7 \%$ (95 \% BI 62,1 \% - 80,0\%). Отже, із ризиком розвитку ускладнення після операції виявлено зв'язок ( $<0,001)$ для наступних факторів (табл. 3 ).

Таким чином виявлено зниження $(\mathrm{p}<0,001)$ ризику розвитку ускладнення після операції при використанні методу Gr=“II" у порівнянні з методом Control. Виявлено тенденцію до зростання $(\mathrm{p}=0,07)$ ризику розвитку ускладнення після операції для стадії неоваскуляризації =3, ВШ=3,7 (95 \% ВI 0,9 - 15,7) у порів-

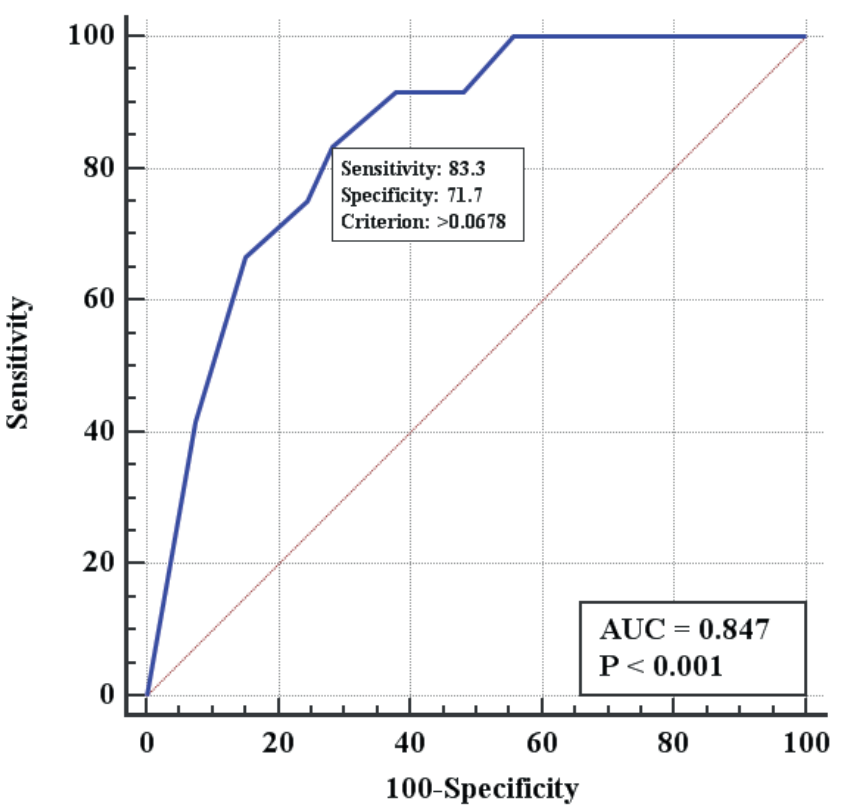

Puc. 2. ROC-крива 3-хфакторної моделі прогнозування ризику розвитку ускладнення після операції (позначено показники чутливості та специфічності для оптимального порогу прийняття рішення) 
нянні зі стадією неоваскуляризації $=2$.

Ризик розвитку післяопераційних ускладнень також пов'язаний зі ступенем та характером неоваскуляризації. При ІІІ-й стадії неоваскуляризації ризик розвитку геморагічних ускладнень збільшується порівняно з неоваскуляризацією II-ї стадії.

Одночасне використання анти-VEGF терапії при хірургії ВНГ зменшує ризик розвитку післяопераційних ускладнень у порівнянні з впливом операції субсклеральної цикловітректомії, що лише тимчасово зменшує концентрацію VEGF- факторів у скловидному тілі.

\section{Висновки}

1. Запропоноване хірургічне лікування вторинної неоваскулярної глаукоми, яке включає одночасне виконання ГНСЕ та СЦВТ, призводить до поетапного зниження ВОТ та зменшення неоваскуляризації, що, таким чином, зменшує кількість інтраопераційних ускладнень до 16 \% (при класичних методиках кількість ускладнень досягає $70 \%$ ).

2. Патогенетично направлене хірургічне лікування хворих на ВНГ призводить до компенсації ВОТ у $86 \%$ хворих без додаткового застосування гіпотензивної терапії.

3. На основі результатів дослідження змін, що виникають у хворих з ВНГ (стадія глаукоми, стадія неоваскуляризації, характер оперативних втручань), розроблено математичну модель прогнозування інтра- та післяопераційних ускладнень.

4. Використання такої математичної моделі дозволить прогнозувати вірогідність ускладнень, пов'язаних із хірургічним втручанням, та провести корекцію лікування.

5. Подальше вивчення механізму розвитку неоваскулярної глаукоми дозволить підвищити ефективність лікування та зменшити кількість і характер ускладнень, які супроводжують хірургічні втручання.

\section{Література}

1. Батманов Ю. Е. Фильтрующая склерцикловитреоэктомия в лечении неоваскулярной глаукомы / Ю. Е. Батманов, А. И. Мовшович, А. П. Нестеров [и др.] // Вестник офтальмологии. - 1985. - № 3. - C. 6-9.

2. Бикбов М. М. Роль дренажа Ахмед в хирургии рефрактерной глаукомы/ М. М. Бикбов, В. К. Суркова, И. И. Хуснитдинов, И. О. Оренбуркина, Р. Р. Хизматуллин, О. В. Чайка // Восток-Запад. Точка зрения. - 2014. - № 1. - С. 103-106.

3. Глушков И. А. Комбинированное лечение вторичной неоваскулярной глаукомы / И. А. Глушков, Ю. И. Рожко, А. О. Кривуж // Актуальные вопросы офтальмологии: X республик. конф. Материалы. - Минск, 2016. - С. 589-590.
4. Ефимова M. H. Неоваскулярная глаукома: диагностика и лечение / М. Н. Ефимова // VII съезд офтальмологов России: тезисы докл. - М., 2000. - Ч. 1. - C. 126.

5. Могилевский С. Ю. Состояние факторов фибринолиза стекловидного тела у больных вторичной неоваскулярной глаукомой / С. Ю. Могилевский, А. Г. Лунева, С. А. Рыков [и др.] // Питання експериментальної та клінічної медицини: Зб. статей. - Донецьк, 2014. - Вип. 18, Т. 4. - С. 94-98.

6. Павлюченко К. П. Результаты комбинированного хирургического лечения вторичной неоваскулярной глаукомы: 3 месяца наблюдения / К. П. Павлюченко, С. Ю. Могилевский, А. В. Савченко // Питання експериментальної та клінічної медицини: Зб. статей. - Донецьк, 2014. - Вип. 18, Т. 1. - C. 209-217.

7. Полунина М. А. Неоваскулярная глаукома: ретроспективный анализ трехлетнего опыта хирургического лечения пациентов / М. А. Полунина, Е. В. Карлова, Е. В. Радайкина [и др.] // Медицинский вестник Башкортостана. - 2016. - Т. 11, № 1. - C. $78-81$.

8. Тульцева C. Окклюзии вен сетчатки (этиология, патогенез, клиника, диагностика, лечение) / С. Тульцева, Ю. Астахов. - СПб.: 2010. - 112 с.

9. Aiello L. P. Vascular endothelial growth factor in ocular fluid of patients with diabetic retinopathy and other retinal disorders / L. P. Aiello, R. L. Avery, P. G. Arrigg [et al.] // N. Engl. J. Med. - 1994. - Vol. 331, No. 22. - P. 1480-1487.

10. Hyung Bin Hwang. Beneficial Effects of Adjuvant Intravitreal Bevacizumab Injection on Outcomes of Ahmed Glaucoma Valve Implantation in Patients with Neovascular Glaucoma: Systematic Literature Review / Hyung Bin Hwang, Jae Wook Han, Hye Bin Yim, Na Young Lee // Journal of ocular pharmacology and therapeutics. - 2015. - Vol. 31 (4).

11. Junki Kwon. Effect of Preoperative Intravitreal Bevacizumab on the Surgical. Outcome of Neovascular Glaucoma at Different Stages/ Junki Kwon and Kyung Rim Sung // Hindawi. Journal of Ophthalmology. - Vol. 2017. - 7 p.

12. Liu Lan. Intravitreal ranibizumab injection combined trabeculectomy versus Ahmed valve surgery in the treatment of neovascular glaucoma: assessment of efficacy and complications / Lan Liu, Yongfeng Xu, Zhu Huang, Xiaoyu Wang // BMC Ophthalmology. - 2016. -Vol. 16.

13. Kim Megan. Angiogenesis in Glaucoma Filtration Surgery and Neovascular Glaucoma-A Review / Megan Kim, Chelsea Lee, Rachael Payne [et al.] // HHS Public Access. Surv Ophthalmol. - 2015. - Vol. 60 (6). - P. 524-535.

14. Kitnarong Naris. A Prospective Study to Evaluate Intravitreous Ranibizumab as Adjunctive Treatment for 
Trabeculectomy in Neovascular Glaucoma / Naris Kitnarong, Chuenjanok Sriyaku, Siriwan Chinwattanakul // Ophthalmol Ther. - 2015. - Vol. 4 (1). - P. 33-41.

15. Tan M. N. Randomized controlled trial of intravitreal ranibizumab versus standard grid laser for macu- lar edema following branch retinal vein occlusion / M. N. Tan, I. L. Mcallister, M. E. Gillies [et. al.] // Am J Ophthalmol. - 2014. - Vol. 157 (1). - P. 237-247.

\title{
СРАВНИТЕЛЬНАЯ ЭФФЕКТИВНОСТЬ КОМБИНИРОВАННОГО МЕТОДА ХИРУРГИЧЕСКОГО ЛЕЧЕНИЯ ВТОРИЧНОЙ НЕОВАСКУЛЯРНОЙ ГЛАУКОМЫ
}

Н. В. Новак

Одним из самых тяжелых осложнений сосудистых заболеваний сетчатки является вторичная неоваскулярная глаукома (ВНГ).

Цель работы - изучение эффективности и безопасности метода хирургического лечения ВНГ, который включает поэтапное снижение внутриглазного давления.

Материалы и методы. Проведен анализ протекания болезни у 118 больных ВНГ.

Результаты и их обсуждение. Предложенный метод обеспечивает гипотензивный эффект у 86,0% больных и уменьшает геморрагические осложнения до $16 \%$.

Выводы. Предложенная комбинированная операция имеет меньшее количество как интра-, так и послеоперационных осложнений, обеспечивает стойкий гипотензивный эффект и сохраняет зрительные функции в отдаленный период.

Ключевые слова: вторичная неоваскулярная глаукома, комбинированное лечение, поэтапное снижение внутриглазного давления, неоваскуляризащия.

\section{COMPARATIVE EFFECTIVENESS OF THE COMBINED METHOD OF SURGICAL TREATMENT OF SECONDARY NEOVASCULAR GLAUCOMA}

\author{
N. V. Novak \\ Kyiv City Clinical Ophthalmological Hospital "Eye Microsurgery Center" \\ of the Ministry of Public Health of Ukraine \\ Kyiv, Ukraine
}

Introduction. One of the most serious complications of retinal vascular disease is secondary neovascular glaucoma (SNG).

Aim. Increase and study the effectiveness and safety of the surgical treatment of VNG, which includes a gradual reduction in intraocular pressure.

Materials and methods. 118 patients with SNG were analyzed.

Results. The proposed method provides an antihypertensive effect in $86.0 \%$ of patients and a decrease in hemorrhagic complications to $16 \%$.

Conclusion. The proposed combined operation has a smaller amount of both intra- and postoperative complications, provides a persistent hypotensive effect and preserves visual functions in the remote period.

Key words: secondary neovascular glaucoma, combined treatment, gradual decrease of intraocular pressure, neovascularization.

Стаття надійшла до редакції 23.02.2018 p. 